\title{
Artmış Lipid Seviyeleri ve Meme Kanseri
}

\author{
Ömer PARLAK ${ }^{1}$ Servet KOCAÖZ ${ }^{2}$
}

\begin{abstract}
$\ddot{\mathbf{O} z}$
Meme kanseri, hem gelişmiş hem de gelişmekte olan ülkelerde kadınlarda görülen en sık kanserdir. Metabolik heterojenite tüm kanserlerde mevcut olabilir. Dislipidemi, bağımsız olarak meme kanseri gelişimi ile ilişkilidir. Bu çalışma, çalışma grubundaki 100 meme kanseri hastasından ve kontrol grubu olarak adlandırılan 100 benzer normal kadınlardan alınan serum örnekleri üzerinde yapıldı. Herhangi bir tedavi uygulamadan önce çalışma grubu ve kontrol grubu üzerinde lipit paterni çalışmaları yapıldı. Toplanan serum örnekleri Total kolesterol (TC), HDL, LDL ve Trigliserit konsantrasyonları açısından incelenmiştir. Çalışma grubunda en genç hasta 35 yaşında, en yaşlı hasta 83 yaşında idi. Ortalama yaş $58,41 \pm 11,01$ yıldı. Kontrol grubunda en genç hasta 30 yaşındaydı ve en yaşlı hasta 80 yaşındayd. TC, LDL, TG seviyeleri bütün evrelerde artmış olarak bulundu ve C-ERB-B2 pozitifliğinde de benzer olan artmıştır. Çalışmamız lipid düzeyleri ile meme kanseri arasındaki ilişkiyi desteklemektedir. Bununla birlikte, bir marker olarak kullanılmak üzere, prospektif de dahil olmak üzere çoklu merkez çalışmalarına ihtiyaç duyulmaktadır.
\end{abstract}

Anahtar Kelimeler: Lipid düzeyi, meme kanseri

\section{Increased Lipids Levels and Breast Cancer}

Ömer PARLAK ${ }^{1}$ Servet KOCAÖZ ${ }^{2}$
Yayın Bilgisi

Gönderi Tarihi:25.09.2018

Kabul Tarihi:27.02.2019

Online Yayın Tarihi:30.06.2019

DOI: 10.26453/otjhs.463786

Sorumlu Yazar

Ömer PARLAK

Eskişehir Yolu no:1 Atatürk Eğitim ve Araştırma Hastanesi Genel

Cerrahi Servisi Bilkent,

Çankaya/Ankara

Tel: 0312 2912525/3771

Mobil: 05053851100

Fax: 03122912706

E-Posta: oparlak@hotmail.com

\begin{abstract}
Breast cancer is the top cancer in women both in the developed and the developing world. Metabolic heterogeneity may be present in all cancers. Dyslipidemia is independently associated with the development of breast cancer. The present study was carried out on serum samples from 100 breast cancer patients named study group and 100 similar age normal women named control group. Lipid pattern studies were carried out on study group and control group before any treatment. The serum samples so collected were examined for Total cholesterol (TC), High density lipoprotein cholesterol (HDL), Low density lipoprotein cholesterol (LDL) and Triglyceride (TG) concentrations. In the study group the youngest patient was of 35 years old and oldest patient was of 83 years. Mean age was $58.41 \pm 11.01$ years. In the control group, the youngest patient was of 30 years and oldest patient was of 80 years. TC, LDL, TG levels increased in all grades, which is similar in the of C-ERB-B2 positive status. Our study supports the relationship between increased lipid levels and breast cancer. However, there is a need for multiple center studies, including prospective, to be used as a marker.
\end{abstract}

Keywords: Lipids level, breast cancer
Article Info

Received:28.09.2018

Accepted:27.02.2019

Online Published:30.06.2019

DOI: $10.26453 /$ otjhs.463786

Corresponding Author

Ömer PARLAK

Eskişehir Yolu no:1 Atatürk Eğitim ve Araştırma Hastanesi Genel Cerrahi Servisi Bilkent, Çankaya/Ankara Tel: 0312 2912525/3771

Mobil: 05053851100

Fax: 03122912706

E-Posta: oparlak@hotmail.com

${ }^{1}$ Yıldırım Beyazıt Üniversitesi Tıp Fakültesi Genel Cerrahi Anabilim Dalı, Ankara

${ }^{2}$ Atatürk Eğitim ve Araştırma Hastanesi Genel Cerrahi Anabilim Dalı, Ankara

\section{INTRODUCTION}

Breast cancer is the top cancer in women both

in the developed and the developing world.

The incidence of breast cancer is increasing in the developing world due to increase life expectancy, increase urbanization and adoption of western lifestyles. Although some 
risk reduction might be achieved with prevention, these strategies cannot eliminate the majority of breast cancers that develop in low- and middle-income countries where breast cancer is diagnosed in very late stages. Therefore, early detection in order to improve breast cancer outcome and survival remains the cornerstone of breast cancer control. ${ }^{1}$ Approximately one-half of newly diagnosed breast cancers can be explained by known risk factors, such as age at menarche, first live birth, menopause, and proliferative breast disease. An additional 10 percent are associated with a positive family history. In addition, risk may be modified by demographic, lifestyle, and environmental factors, although their association with breast cancer risk has not been clearly demonstrated. ${ }^{2}$

Metabolic heterogeneity may be present in all cancers Identifying biologic markers associated with metabolic heterogeneity, breast cancer subtype and prognosis is of importance in order to discover potential targets for treatment and optimize breast cancer outcomes. ${ }^{3}$ Dyslipidemia is independently associated with the development of breast cancer. ${ }^{4}$ But, studies contradict. $^{5}$ Recently, the body mass index (BMI) has been shown to be distributed differently to the breast cancer molecular subtypes, ${ }^{6}$ and has also been supported by others. ${ }^{7,8}$ Triglycerides serve as an independent source for fatty acid oxidation, ${ }^{9}$ an important process that supports the carcinogenic potential of triglycerides and promotes cell proliferation and tumor growth. ${ }^{10}$ However, the relationship between pre-diagnostic triglycerides and breast cancer development remains unclear as a molecular subtype. ${ }^{11} \mathrm{It}$ has also been suggested that cholesterol plays a role in breast cancer progression. ${ }^{12}$ In contrast, HDL has anti-inflammatory properties $^{13}$ and is inversely associated with the risk of breast cancer. ${ }^{14}$ Low HDL may be associated with higher estrogen levels and absolute mammographic intensity. ${ }^{15-17}$ In addition, different lipoproteins show that the effect of HDL-cholesterol on breast cancer prognosis is different from the lower breast cancer phenotype, ${ }^{18}$ according to progesterone receptor expression. ${ }^{19}$

The relation between serum lipids levels and breast cancer risk is unclear; because cholesterol is the precursor to sex steroid hormones, higher levels of cholesterol could possibly increase risk of breast cancer. Present study was planned to evaluate the relationship between serum lipids and breast cancer by menopausal status, type and stage of cancer.

\section{MATERIAL AND METHODS}

After Institutional Ethical Committee approval, the present study was carried out on 
serum samples from 100 breast cancer patients named study group and 100 similar age normal women named control group. The control group consists of healthy women who were not taking any hormone preparation. Having history of diabetes, hypertension, coronary artery disease, metabolic syndrome, endocrine disorders, renal and hepatic failure or taking oral contraceptive or any form of hormonal medication, having family history of breast cancer or suffering from any other malignancy/benign breast disorders were excluded from the study.

The diagnosis of breast carcinoma was made by Tru-Cut Biopsy and confirmed by histopathological examination. Lipid pattern studies were carried out on study group and control group before any treatment. Whole blood sample of $5 \mathrm{ml}$ was taken from each participant of study group and control group. After clotting, sample was centrifuged for serum separation. All patients in the study group and the control group were fasted for at least 8 hours before taking samples. The serum samples so collected were examined for Total cholesterol (TC), High density lipoprotein cholesterol (HDL), Low density lipoprotein cholesterol (LDL) and Triglyceride (TG) concentrations. In our study, there was no significant distribution in pre and postmenopausal patients.

\section{Statistical Analysis}

All data was analysed using the Statistical Package for Social Sciences (SPSS) software computer program version. Data were expressed as mean (M) and standard deviation (SD) following analyses using student t-test, which was performed for comparison between control and patient groups. A value of $\mathrm{p}<0.05$ was considered significant.

\section{RESULTS}

In our study was carried out on serum samples from 100 breast cancer patients named study group and 100 similar age normal women named control group. In the study group the youngest patient was of 35 years old and oldest patient was of 83 years. Mean age was $58.41 \pm 11.01$ years. In the control group, the youngest patient was of 30 years and oldest patient was of 80 years. Mean age of the control group was $56.86 \pm 10.48$ years (Table 1). The measured lipid levels (LDL, HDL, TC, and TG) in both groups are shown in Table 2 . The LDL, TC and TG levels in the study group were significantly higher. The HDL level was also found to be lower according to the control group.

In this study, 40 patients were grade 3, 44 patients were grade 2, and 16 patients were grade 1. LDL, TC and TG levels were found to be higher in all stages of breast cancer patients than in the control group at all stages. 
Although there was no significant difference between the grades (Table 3 ).

Lipid levels were determined according to $\mathrm{C}$ ERB-B2, (also known as HER2) as positive and negative status. LDL and TC levels were found to be higher in the study group compared to all C-ERB-B2 positivity levels and were statistically significant. TG, was found to be increased in C-ERB-B2 $3+$ and this was statistically significant. HDL levels were also lower in C-ERB-B2 $1+$ and $2+$ compared to the control group and statistically significant. In contrast, HDL levels were found to be similar in patients with C-ERB-B2 3+ (Table 4).

\section{DISCUSSION AND CONCLUSION}

Breast carcinoma is one of the major surgical problems developing besides advanced nations. Relationship between serum lipid profiles and breast cancer are uncertain. Local eating habits increased fat diet, increased alcohol consumption, smoking, country of residence, pregnancy, endogenous hormones, less exercise, environmental factors together with genetics predisposition are important factors related to breast carcinoma. ${ }^{20-23}$ Current study, it is planned to evaluate the relationship with the lipid profile breast cancer.

Study by Ray at al. various serum lipid levels, namely triglycerides, total cholesterol, HDL,
LDL. Triglycerides, total cholesterol and LDL cholesterol were significantly Breast cancer cases are higher than controls. They included 138 histologically proven cases of breast cancer along with 146 control females in their study. ${ }^{24}$ Study by Xing Li and colleagues in 1044 breast cancer patients Preoperative serum levels of TG and HDL have been shown to be independent predictors of outcome in breast cancer patients. ${ }^{25}$ Similarly in our research, the LDL level of the study group was determined as $123,19 \mathrm{mg} / \mathrm{dl}$ and the mean of the control group was found to be $95.83 \mathrm{mg} / \mathrm{dl}$, which was statistically significantly higher ( $\mathrm{p}$ value $0.002)$.

In the present study on comparison of $\mathrm{TC}$ among study group and control group it was found that mean TC among study group was $198.43 \mathrm{mg} / \mathrm{dl}$ and in control group was 171.97 $\mathrm{mg} / \mathrm{dl}$ with $\mathrm{p}$-value $0.003(<0.05)$, which is significant. Bhat et al. $^{26}$ studied over 120 women, including 60 breasts. Cancer patients with 25 to 80 age group and 60 healthy women as a control with similar age range. They evaluated the role of Lipid Profile in breast cancer. They saw a significant increase TC, TG and LDL controls. Both pre-menopausal and TG and TG gains and post-menopausal cases of HDL-cholesterol not changed. We have not separated patients pre or postmenopausal. In the study group, the mean HDL was $49.95 \mathrm{mg} / \mathrm{dl}$ and the control group 
average was $57.24 \mathrm{mg} / \mathrm{dl}$. This is statistically significant (p: $0.017<0.05)$.

In this study on the comparison of TG between the study group and the control group, it was found that the mean TG was $83.69 \mathrm{mg} / \mathrm{dl}$ in the study group and $149.72 \mathrm{mg} / \mathrm{dl}$ in the control group with $\mathrm{p}$ value of $0,001(<0.05)$, this is important. In a study by Manuela GagoDominguez et al. the risk of breast cancer in C-ERB-B2 negative was significantly increased by the increase of circulating triglyceride levels. ${ }^{27}$

In this study, LDL, TC and TG levels were found to be higher in all grades of breast cancer patients than in the control group at all stages $(p<0.05)$. Although there was no significant difference between the grades. In a study by Raza et al. $^{28}$ hyperlipidemia was significantly high in breast cancer patients with lymph node metastasis. On increase in tumor grade I to II, increase in total cholesterol (4\%), LDL-cholesterol $23 \%$ and $11 \%$ increase in triglycerides was observed. On tumor size increase from $\leq 2$ to $2.5 \mathrm{~cm}$, increase observed in total cholesterol $(1.7 \%)$ triglycerides $(2 \%)$ and LDL (3\%) whereas HDL was (2\%) low.

In our study, as the C-ERB-B2 levels increased, LDL and TC levels were also increased. TG, was found to be increased in $\mathrm{C}$ ERB-B2 3+. HDL levels were also lower in CERB-B2 $1+$ and 2+. In contrast, HDL levels were found to be similar in patients with $\mathrm{C}$ -
ERB-B2 3+. Dominguez et al. the risk of breast cancer in C-ERB-B2 negative was significantly increased by the increase of circulating triglyceride levels. ${ }^{27}$

Our study supports the relationship between increased lipid levels and breast cancer. Thus, TC, LDL, TG levels increased in all grades, which is similar in the of C-ERB-B2 positive status. However, there is a need for multiple center studies, including prospective, to be used as a marker.

\section{REFERENCES}

1. World Health Organization (WHO). Available from: http://www.who.int/cancer/detection/breast cancer/en/ Accessed: 11.06.2018.

2. Siegel RL, Miller KD, Jemal A. Cancer Statistics, 2017. CA Cancer J Clin 2017; $67: 7$.

3. Martinez-Outschoorn UE, Peiris-Pages M, Pestell RG, Sotgia F, Lisanti MP. Cancer metabolism: a therapeutic perspective. Nat Rev Clin Oncol. 2017;14(1):11-31.

4. Cibeira GH, Giacomazzi J, Aguiar E, et al. Apolipoprotein E genetic polymorphism, serum lipoprotein levels and breast cancer risk: a case-control study. Mol Clin Oncol. 2014;2(6):1009-15.

5. His M, Dartois L, Fagherazzi G, et al. Associations between serum lipidsand breast cancer incidence and survival in the 
E3N prospective cohort study. Cancer Causes Control. 2017;28(1):77-88.

6. Gershuni V, Li YR, Williams AD, So A, Steel L, Carrigan E, Tchou J. Breast cancer subtype distribution is different in normal weight, overweight, and obese women. Breast Cancer Res Treat. 2017;163(2):375381. Doi: 10.1007/s10549-017-4192-x.

7. Agresti R, Meneghini E, Baili P, et al. Association of adiposity, dysmetabolisms, and inflammation with aggressive breast cancer subtypes: a cross-sectional study. Breast Cancer Res Treat. 2016;157(1):17989.

8. Kwan ML, Kroenke CH, Sweeney C, et al. Association of high obesity with PAM50 breast cancer intrinsic subtypes and gene expression. BMC Cancer. 2015;15:278.

9. Balaban S, Lee LS, Schreuder M, Hoy AJ. Obesity and cancer progression: is there a role of fatty acid metabolism? Biomed Res Int. 2015;2015:274585.

10. Saavedra-Garcia P, Nichols K, Mahmud Z, Fan LY, Lam EW. Unravelling the role of fatty acid metabolism in cancer through the FOXO3-FOXM1 axis. Mol Cell Endocrinol. 2017. S0303-7207(17):300163.

11. Li X, Tang H, Wang J, et al. The effect of preoperative serum triglycerides and highdensity lipoprotein-cholesterol levels on the prognosis of breast cancer. Breast (Edinburgh,Scotland). 2017;32:1-6.
12. Warner M, Gustafsson JA. On estrogen, cholesterol metabolism, and breast cancer. N Engl J Med. 2014;370(6):572-3.

13. His M, Zelek L, Deschasaux M, et al. Prospective associations between serum biomarkers of lipid metabolism and overall, breast and prostate cancer risk. Eur J Epidemiol. 2014;29(2):119-32.

14. Furberg AS, Veierod MB, Wilsgaard T, Bernstein L, Thune I. Serum high-density lipoprotein cholesterol, metabolic profile, and breast cancer risk. J Natl Cancer Inst. 2004;96(15):1152-60.

15. Furberg AS, Jasienska G, Bjurstam N, Torjesen PA, Emaus A, Lipson SF, Ellison PT, Thune I. Metabolic and hormonal profiles: HDL cholesterol as a plausible biomarker of breast cancer risk. The Norwegian EBBA study. Cancer Epidemiol Bio-markers Prev. 2005;14(1):33- 40

16. Flote VG, Frydenberg H, Ursin G, Iversen A, Fagerland MW, Ellison PT, Wist EA, Egeland T, Wilsgaard T, McTiernan A, et al. High-density lipoprotein-cholesterol, daily estradiol and progesterone, and mammographic density phenotypes in premenopausal women. Cancer Prev Res (Phila). 2015;8(6): 535-44.

17. Emaus A, Veierod MB, Tretli S, et al. Metabolic profile, physical activity, and mortality in breast cancer patients. Breast Cancer Res Treat. 2010;121(3):651-60. 
18. Fan Y, Ding X, Wang J, et al. Decreased serum HDL at initial diagnosis correlates with worse outcomes for triple-negative breast cancer but not non-TNBCs. Int J Biol Markers. 2015;30(2):e200-7.

19. Flote VG, Vettukattil R, Bathen TF, et al. Lipoprotein subfractions by nuclear magnetic resonance are associated with tumor characteristics in breast cancer. Lipids Health Dis. 2016;15:56.

20. Gillet CE, Happerfield LC. Breast cancer from clinic to laboratory. Br J Biomed Sci. 1997;54:47-56.

21. Henerson MM. Nutritional aspects of breast cancer. Cancer. 1995;76:2053-58.

22. Kelsey JL, Gammon MD, John EM. Reproductive factors and breast cancer. Cancer Epidemiol Res. 1993;15:36-47.

23. Lai LC. Metabolism of dehydroepiandrosterone sulfate by breast cysts:possible role in the development of breast cancer. Cancer Detect Prev. 1995;19:441-45.

24. A Ray, SL Dayalu Naik, RS Rautela, BK Sharma. Serum lipids, lipoproteins and sex hormone binding globulin in breast cancer. J Clin Biochem. 2001;6(1):101-05.

25. Li X, H. Tang, J. Wang, et al. The effect of preoperative serum triglycerides and highdensity lipoprotein-cholesterol levels on the prognosis of breast cancer. The Breast. 2017;32,1-6. Doi: 10.1016/j.breast.2016.11.024.
26. Bhat SA, Mir MR, Majid S, et al. Serum Lipid Profile of Breast Cancer Patients in Kashmir. J Invest Biochem. 2013;2(1):2631.

27. Gago-Dominguez M, Calaza M, MuñozGarzon V, Martinez ME, Castelao JE. Circulatnn lipids and breast cancer subtypes in a Spanish populaton. American Association for Cancer Research. Cancer Research. 2017;77(13 Supplement):22692269. Doi: 10.1158/1538-7445.AM20172269.

28. Raza U, Asif MR, Rehman AB, Sheikh A. Hyperlipidemia and hyper glycaemia in Breast Cancer Patients is related to disease stage. Pakistan Journal of Medical Sciences. 2018;34(1):209-14. Doi: 10.12669/pjms.341.14841. 
Table 1: Distribution according to age groups

\begin{tabular}{lcc}
\hline Age Groups & Control group (n) & Study group (n) \\
$\leq 40$ & 8 & 3 \\
$41-50$ & 15 & 13 \\
$51-60$ & 47 & 51 \\
$61-70$ & 18 & 22 \\
$>70$ & 12 & 11 \\
Total & 100 & 100 \\
Mean age & $56.86 \pm 10.48$ & $58.41 \pm 11.01$ \\
\hline
\end{tabular}


Table 2. Lipid profile of study and control groups

\begin{tabular}{lccc}
\hline $\begin{array}{l}\text { Lipids Levels } \\
(\mathbf{m g} / \mathbf{d l})\end{array}$ & $\begin{array}{c}\text { Study Group } \\
\left(\text { Average } \pm \text { SD }^{*}\right)\end{array}$ & $\begin{array}{c}\text { Control Group } \\
(\text { Average } \pm \text { SD) }\end{array}$ & p-value \\
LDL & $123.19 \pm 40.61$ & $95.83 \pm 19.39$ & $\mathbf{0 . 0 0 2}$ \\
HDL & $49.95 \pm 14.43$ & $57.24 \pm 11.71$ & $\mathbf{0 . 0 1 7}$ \\
Total cholesterol & $198.43 \pm 43.73$ & $171.97 \pm 22.67$ & $\mathbf{0 . 0 0 3}$ \\
Triglycerides & $149.72 \pm 52.21$ & $83.69 \pm 38.32$ & $\mathbf{0 . 0 0 1}$ \\
\hline
\end{tabular}

*SD: Standart Deviation; **p-value $<0.05$ - significant, $>0.05$ - Non significant 
Table 3. Lipid profile of Women with Breast Cancer according to grade

\begin{tabular}{lcccc}
\hline & \multicolumn{4}{c}{ Lipids Levels (mg/d) (Average \pm SD) } \\
LDL & HDL & Total cholesterol & Triglycerides \\
Control group $(\mathbf{n = 1 0 0})$ & $95.83 \pm 19.39$ & $57.24 \pm 11.71$ & $171.97 \pm 22.67$ & $83.69 \pm 38.32$ \\
Grade 1 $(\mathbf{n = 1 6}$ & & Study Group & & \\
p-value* & $112.18 \pm 26.37$ & $52.51 \pm 12.02$ & $186.91 \pm 23.68$ & $135.45 \pm 38.02$ \\
Grade 2 $(\mathbf{n = 4 4 )}$ & $\mathbf{0 . 1 8 7 9}$ & $\mathbf{0 . 0 0 3 6}$ & $\mathbf{0 . 1 6 6 3}$ & $\mathbf{0 . 0 0 0 2}$ \\
p-value & $127.54 \pm 32.66$ & $45.09 \pm 8.10$ & $208.29 \pm 22.14$ & $141.69 \pm 52.43$ \\
Grade 3 $(\mathbf{n = 4 0})$ & $\mathbf{0 . 0 0 0 2}$ & $\mathbf{0 . 2 5 1 0}$ & $\mathbf{0 . 0 0 0 1}$ & $\mathbf{0 . 0 0 0 4}$ \\
p-value & $122.19 \pm 30.14$ & $48.77 \pm 12.63$ & $191.39 \pm 24.53$ & $155.35 \pm 66.06$ \\
\hline
\end{tabular}

*p-value $<0.05$ - significant, $>0.05$ - Non significant 
Table 4. Lipid levels of C-ERB-B2 positive and negative status

\begin{tabular}{|c|c|c|c|c|c|}
\hline & & & Lipids Levels & /dl) (Average \pm SD & \\
\hline & & LDL & HDL & Total cholesterol & Triglycerides \\
\hline & Control Group & $95.83 \pm 19.39$ & $57.24 \pm 11.71$ & $171.97 \pm 22.67$ & $83.69 \pm 38.32$ \\
\hline & Negative $(n=39)$ & $123.33 \pm 41.67$ & $48.50 \pm 12.34$ & $197.77 \pm 43.60$ & $160.37 \pm 54.63$ \\
\hline & p-value* & 0.001 & 0.004 & 0.004 & 1 \\
\hline 2 & $1+(n=19)$ & $116.36 \pm 24.03$ & $53.57 \pm 9.74$ & $195.64 \pm 25.81$ & $117.50 \pm 43.45$ \\
\hline 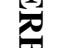 & p-value & 0.003 & 0.162 & 0.002 & 0.007 \\
\hline 总 & $2+(n=20)$ & $128.07 \pm 40.92$ & $44.93 \pm 13.94$ & $191.73 \pm 46.87$ & $158.20 \pm 62.84$ \\
\hline & p-value & 0.001 & 0.002 & 0.033 & 1 \\
\hline & $3+(n=22)$ & $124.22 \pm 49.27$ & $53.72 \pm 19.44$ & $207.28 \pm 52.41$ & $151 \pm 72.11$ \\
\hline & p-value & 0.004 & 0.22 & 0.001 & 0.003 \\
\hline
\end{tabular}

*p-value $<0.05$ - significant, $>0.05-$ Non significant. 